\title{
PENGEMBANGAN SISTEM DIGITAL CHECKER BERBASIS APLIKASI MOBILE ANDROID SEBAGAI PENCATATAN RITASE SECARA REAL TIME PADA PT. SATRIA BAHANA SARANA
}

\author{
Ahmad Isnaini Sugiarta ${ }^{1)}$ dan Karmono ${ }^{1)}$ \\ ${ }^{1)}$ Departement Management Information System (MIS), PT. Satria Bahana Sarana,
}

\begin{abstract}
ABSTRAK
Pengembangan sistem digital checker merupakan tranformasi dari sistem manual yang di distribusikan ke dalam bentuk digital berbasis aplikasi mobile android. Selama ini proses pencatatan setiap ritase dilakukan oleh checker. Checker adalah karyawan yang secara khusus melakukan pencatatan ritase. Proses pencatatan ritase yang dilakukan saat masih bersifat manual menggunakan kertas, dan hasil dari proses pencatatan manual melalui kertas tersebut kemudian diolah dan dianalisa pada satuan kerja Operasional Control Center (OCC). Setelah proses pengolahan data dan analisa yang dilakukan oleh satuan kerja OCC, barulah kemudian dilaporkan ke management. Dari penerapan sistem checker manual tersebut dapat menyebabkan proses pengambilan keputusan bisnis apabila dilihat dari sisi management kurang efektif dan efesien. Selain itu juga dibutuhkan waktu yang lama untuk mengetahui serta memutuskan pencapaian produksi secara ideal berdasarkan kriteria yang telah ditentukan. Oleh sebab itu maka dibutuhkan media perantara berupa sistem aplikasi berbasis mobile android. Tujuan dari pengembangan sistem digital checker ini adalah untuk mengalihkan sistem yang selama ini manual menjadi digitalisasi yaitu pencatatan ritase menggunakan mobile android pada PT. Satria Bahana Sarana. Metodologi dalam penelitian ini adalah penelitian tindakan (action research), dengan pendekatan metode 4-D (Define, Design, Develop, Disseminate) yang digunakan dalam pengembangan sistem digital checker. Adapun aplikasi yang dibangun berbasis android menggunakan bahasa pemograman PHP dan database MySQL, Indexing \& Elastic for (temporary saving) serta web service API (Application Programming Interface), TypeScript. Implementasi akhir dari pengembangan sistem digital checker ini dapat mempercepat dan memberikan informasi ritase melalui penginputan data secara langsung oleh checker dengan sistem aplikasi mobile android, sehingga proses ritase dapat diketahui dengan cepat dan tepat karena data disajikan secara real time selama 24 Jam. Sistem digital checker berbasis aplikasi android telah diuji coba pada PT. Satria Bahana Sarana di site Bangko pit 1 utara dan site Mahayung. Dampak dari penerapan aplikasi digital checker ini juga dapat meminimalisir penumpukan dan penggunaan kertas.
\end{abstract}

Kata Kunci : digital checker, ritase, android, 4D, PT. Satria Bahana Sarana

\begin{abstract}
The development of a digital checker system is a transformation of a manual system that is distributed into digital form based on an android mobile application. The during this recording process, each participant is carried out by the examiner. Inspector is an employee who specifically records the reality. The process of recording the ritase is done while still manually using paper, and the results of the manual recording process through paper are then processed and analyzed in the Operational Control Center (OCC) departement. After the data processing and analysis carried out by the OCC departement, it is then reported to management. From the application of this manual inspection system, it can cause the decision making process taken by the management to be less effective and efficient. In addition it takes a long time to be discussed and also determine the ideal production in accordance with predetermined criteria. Therefore we need media related to the android mobile-based application system. The purpose of the development of this digital checker system is to move the system that has been manually into digitization, namely the recording
\end{abstract}


of ritase using an android phone at PT. Satria Bahana Sarana. The methodology in this research is action research, by studying the 4-D (Define, Design, Develop, Disseminate) method used in the development of digital inspection systems. Android based applications use the PHP programming language and MySQL database, Indexing \& Elastic for (temporary storage) and web service API (Application Programming Interface), TypeScript. The final implementation of the development of the digital checker system can accelerate and provide social information through inputting data directly by the checker with the android mobile application system, so that the security process can be supported quickly and precisely in accordance with the data presented in real time for 24 hours. Android based digital checker system has been tested on PT. Satria Bahana Sarana at Bangko site pit 1 north and Mahayung site. The impact of implementing this digital checking application can also minimize paper buildup and use

Keywords: digital checker, ritase, android, 4D, PT. Satria Bahana Sarana

\section{A. PENDAHULUAN}

Perkembangan teknologi dan informasi saat ini berkembang dengan pesat, termasuk dalam industri pertambangan, baik itu berupa komoditi emas, timah, batubara dan lain sebagainya. Dalam industri pertambangan, peran teknologi menjadi salah satu nilai tambah agar mampu memenangkan persaingan. Terlebih lagi saat ini sudah memasuki era revolusi industri 4.0. Menurut Ningsih (2019), istilah revolusi industri 4.0 pertama kali muncul di tahun 2012, di perkenalkan oleh Pemerintah Jerman saat pelaksanaan proyek strategi teknologi moderen Jerman. Sejalan dengan perkembangan revolusi industri, PT. Satria Bahana Sarana (SBS) sebagai salah satu perusahaan mining solution jasa penambangan secara terus menerus dan berkesinambungan melakukan inovasi teknologi terkait proses bisnis tambang dan alur proses data produksi.

PT. Satria Bahana Sarana memiliki Izin Usaha Jasa Pertambangan (IUJP) Nomor 560.K/30/DJB/2015 Tanggal 08 April 2015. Sebagai salah satu bagian dari group PT. Bukit Asam, Tbk melalui manajemen PT. Bukit Multi Investama (BMI) dengan komposisi saham $95 \%$ dan $5 \%$ komposisi saham PT. Bukit Asam Kreatif (BAK). Bagian terpenting yang harus dilakukan perbaikan yaitu pada alur proses data produksi, sehingga semua pihak pengambil keputusan dengan cepat mengetahui data atau informasi sebagai dasar acuan untuk perencanaan selanjutnya.

Menurut Prodjosumarto (1993), kegiatan pemuatan dan pengangkutan pada kegiatan penambangan adalah suatu kegiatan yang bertujuan untuk memindahkan material hasil penggalian ke tempat penimbunan (disposal) ataupun ke stockpile dengan menggunakan alat-alat mekanis. Proses pemindahaan material menggunakan alat-alat mekanis menggunakan alat berat seperti Dump Truck (DT) Scania, Haul Truck HD 777, 465 dan unit-unit alat berat lainnya. Saat pemindahaan muatan batubara (coal) maupun tanan lapisan atas (overburden) pada setiap ritase akan di catat oleh checker. Checker adalah karyawan PT. SBS yang secara khusus melakukan pencatatan. Untuk itu diperlukan langkah kongkrit untuk pengembangan sistem digital checker yang dapat memudahkan pekerjaan checker melalui pengembangan sistem digital checker.

Pengembangan sistem digital checker merupakan tranformasi dari sistem manual yang di distribusikan ke dalam bentuk digital berbasis aplikasi mobile android dengan menggunakan bahasa pemograman PHP (akronim dari rekursif Hypertext Preprocessor), yaitu bahasa pemograman yang di kembangkan untuk pemograman web. PHP dalam penelitian ini digunakan untuk membangun sebuah CMS (Content Management System) dan MySQL (My Structure Query Language) sebagai database sistem. Juhara (2016), android adalah sistem operasi berbasis linux yang di modifikasi untuk perangkat bergerak (mobile devices) yang terdiri dari sistem operasi, middleware, dan aplikasi-aplikasi utama. Sedangkan menurut Anhar (2010), MySQL adalah sebuah perangkat lunak sistem manajemen basis data SQL (Structure Query Language) dari sekian 
banyak DBMS (Database Management System) seperti Oracle, MS SQL, Postgre SQL, dan lainnya.

Selama ini proses pencatatan setiap ritase dilakukan oleh checker. Proses pencatatan ritase yang dilakukan saat ini masih bersifat manual menggunakan kertas, dan hasil dari proses pencatatan manual melalui kertas tersebut kemudian diolah dan dianalisa pada satuan kerja Operasional Control Center (OCC). Setelah proses pengolahan data dan analisa yang di lakukan oleh satuan kerja OCC, barulah kemudian di laporkan ke management. Dari penerapan sistem checker manual tersebut dapat menyebabkan proses pengambilan keputusan bisnis, apabila dilihat dari sisi management kurang efektif dan efesien. Selain itu juga dibutuhkan waktu yang tidak terukur untuk mengetahui informasi serta memutuskan pencapaian produksi secara ideal berdasarkan kriteria yang telah ditentukan management.

Berdasarkan latar belakang yang telah penulis uraikan diatas maka dalam penelitian ini penulis merumuskan beberapa permasalahan antara lain adalah bagaimana mengembangkan sistem digital checker berbasis aplikasi mobile android dan bagaimana melakukan uji coba untuk mengetahui proses pengambilan keputusan sesuai dengan ketersediaan real time data checker. Untuk menjawab masalah yang sudah dirumuskan sebelumnya maka penulis kemudian menentukan tujuan dari penelitan ini adalah mengembangkan sistem checker dari manual menjadi digital berbasis aplikasi mobile android dan melakukan uji coba serta analisis terhadap penggunaan sistem digital checker yang dapat digunakan dalam pengambilan keputusan dan perencanaan bisnis selanjutnya.

\section{B. METODOLOGI PENELITIAN}

Penelitian ini dilakukan di dua lokasi yaitu site Banko pit 1 Utara dan site Mahayung yang ada dalam ruang lingkup bisnis PT. Satria Bahana Sarana. Waktu penelitian yang dilakukan dalam pengembangan aplikasi checker digital adalah selama tiga bulan, yaitu dari bulan Mei 2018 sampai dengan Agustus 2018. Penelitian ini termasuk ke dalam penelitian tindakan (action research). Zuriah (2003: 54) mengemukakan bahwa penelitian tindakan menekankan pada kegiatan (tindakan) dengan mengujicobakan suatu ide ke dalam praktek atau situasi nyata dalam skala mikro yang diharapkan kegiatan tersebut mampu memperbaiki, meningkatkan kualitas, dan melakukan perbaikan sosial. Dengan menggunakan metodologi penelitian tindakan melalui pendekatan metode four D (4D). Meta (dalam Thiagarajan, dkk : 1974), metode penelitian model 4D terdiri dari empat tahapan antara lain adalah define, design, develop dan disseminate. Secara garis besar tahapan penelitian dapat dilihat pada gambar 1 dibawah ini ;

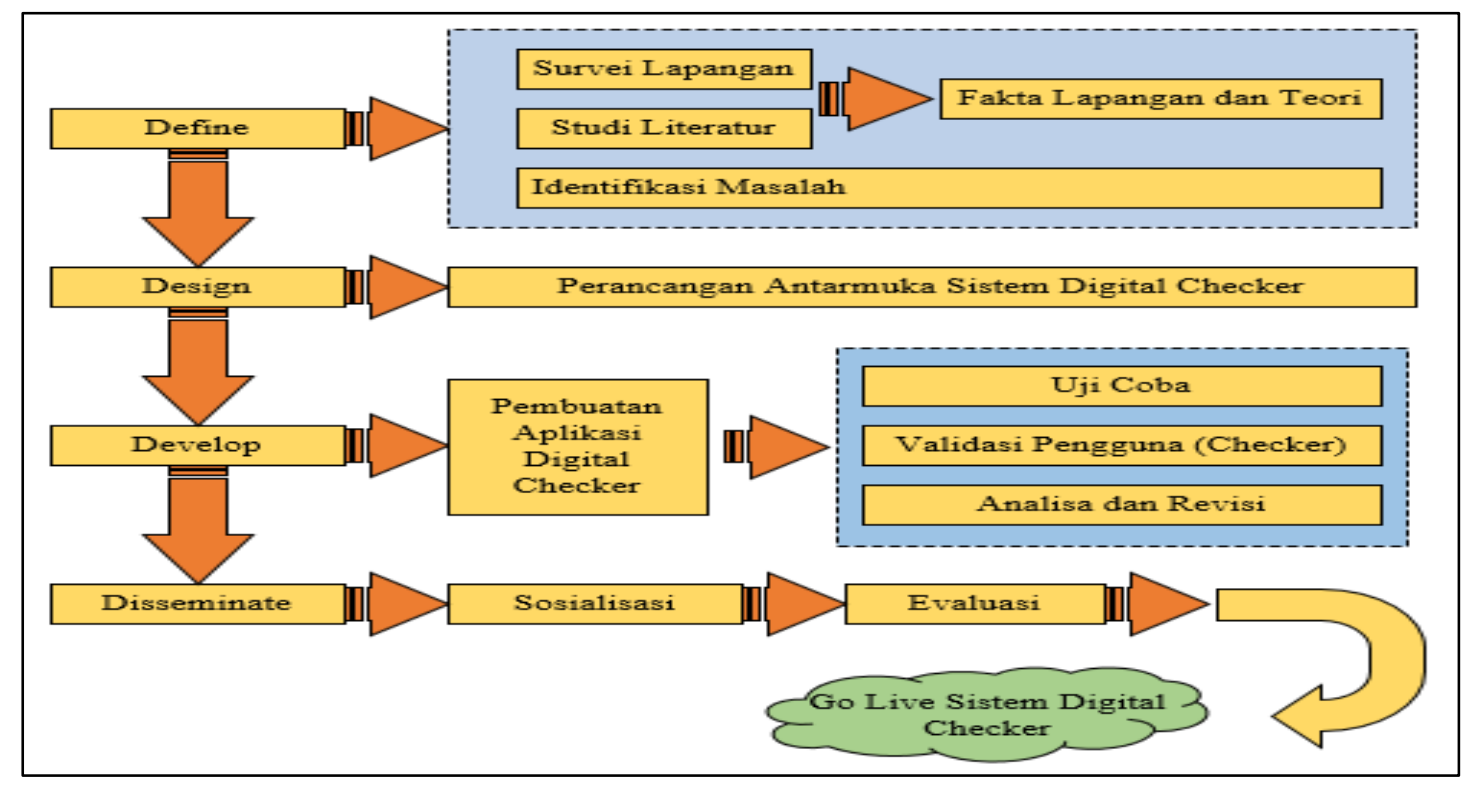


Gambar 1. Diagram alir tahapan penelitian

Penelitian ini terdiri dari empat tahapan seperti terlihat pada gambar 1 diagram alir tahapan penelitian. Dari setiap tahapan penelitian memiliki keterkaitan satu sama lainnya. Dari tahapan penelitian tersebut, supaya lebih mudah di pahami maka penulis uraikan sebagai berikut ;

1. Tahap pendahuluan atau define adalah mempelajari dokumentasi checker manual dan menganalisa alur kerja dari proses checker dengan survei lapangan serta ditunjang dengan studi literatur. Dari survei lapangan dan studi literatur tersebut maka mendapatkan fakta lapangan sebagai identifikasi masalah yang akan diselesaikan. Selanjutnya analisa kebutuhan untuk perangkat keras (hardware), perangkat lunak (software) dan user atau pengguna yang akan menggunakan aplikasi digital checker (brainware).

2. Setelah selesai pada tahapan define dan analisa yang dibutuhkan, selanjutnya masuk ke tahap design. Pada tahapan ini penulis membuat storyboard, bagan struktur pengembagan aplikasi digital checker dan desain antar muka sistem digital checker.

3. Kemudian di tahapan berikutnya, tahap develop yaitu pembuatan aplikasi menggunakan bahasa pemograman PHP dan database MySQL, Indexing \& Elastic for (temporary saving) serta web service API (Application Programming Interface), TypeScript. Pada fase develop ini juga di lakukan uji coba, validasi oleh pengguna apakah sistem digital checker yang dibuat sudah mewakili kebutuhan pekerjaan lapangan dari pengguna, dalam hal ini checker yang akan menggunakan aplikasi digital checker, kemudian analisa serta revisi sebagai penyempurnaan sistem.

4. Tahapan terakhir adalah disseminate, yaitu sosialisasi penggunaan digital checker, baik ke karyawan mapun ke management. Selanjutnya evaluasi ulang dan terakhir Go Live digital checker berbasis mobile android.

\section{HASIL DAN PEMBAHASAN}

Sebelum membahas pengembangan sistem digital lebih lanjut, berikut ini penulis jelaskan terlebih dahulu proses bisnis pencatatan ritase produksi secara manual dan use case modeling fungsionalitas sistem secara digital. Dalam pengembangan digital checker, penelitian ini juga melibatkan kerja sama dengan konsultan pertambangan, Tura Technology. Untuk memberikan pemahaman bagaimana proses pencatatan checker manual dapat di lihat pada ilustrasi gambar 2 dibawah ini.

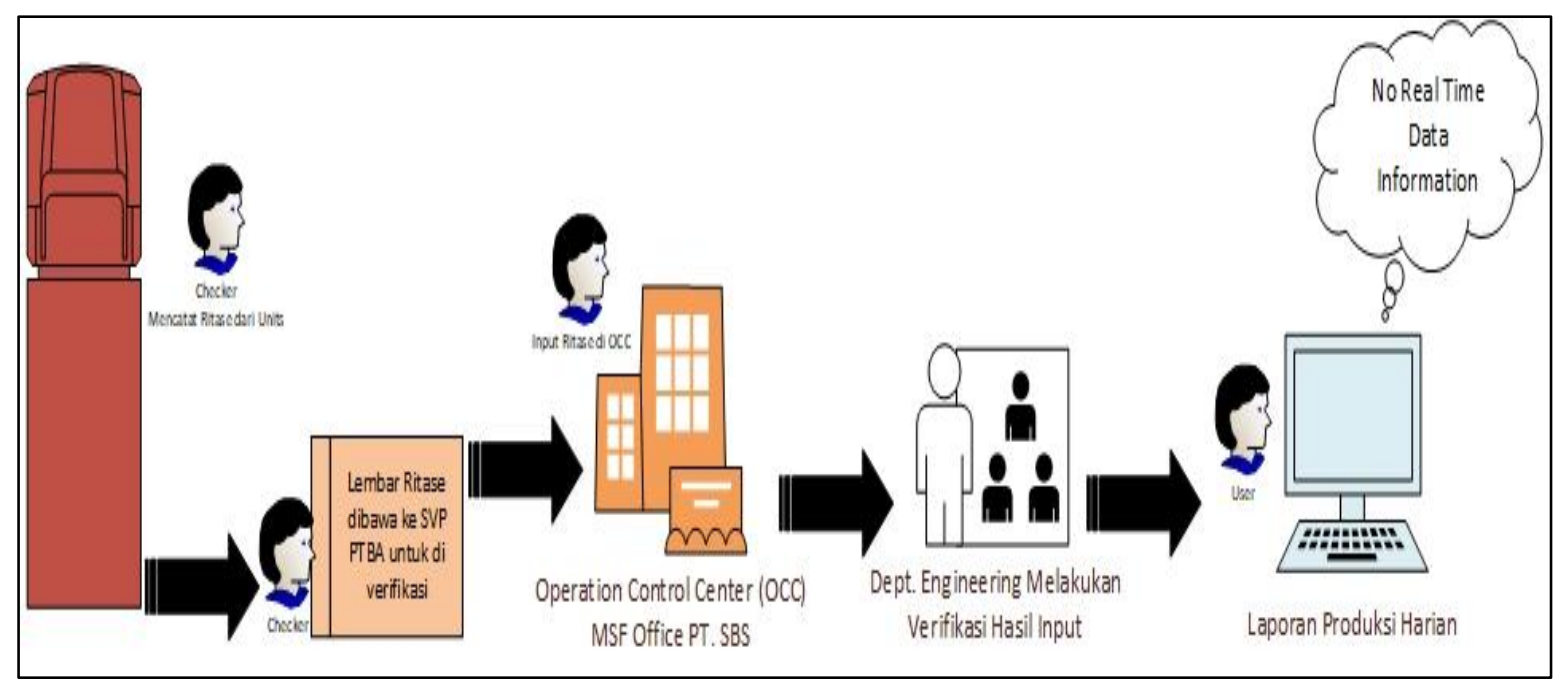

Gambar 2. Alur proses checker manual

Gambar 2 di atas menjelaskan proses awalnya checker melakukan pencatatan ritase dari units, kemudian lembar di bawa ke Supervisor PTBA untuk dilakukan verifikasi, selanjutnya lembar ritase di bawa ke satuan kerja Operation Control Center (OCC) dan kemudian dianalisa oleh 
engineering. Untuk mendapatkan infomasi dari checker, terlihat dari alur proses seperti gambar 2 diatas tidak bisa langsung secara real time.

Dalam penelitian ini penulis menggunakan use case untuk memodelkan fungsionalitasfungsionalitas dari sistem digital checker. Ada 4 aktor yang terhubung dengan sistem. Masingmasing aktor memiliki use case untuk login ke dalam sistem. Login tersebut digunakan untuk melihat dashboard real time data overburden dan coal. Berikut ini merupakan proses bisnis pencatatan ritase produksi secara digital dapat di lihat pada Gambar 3.

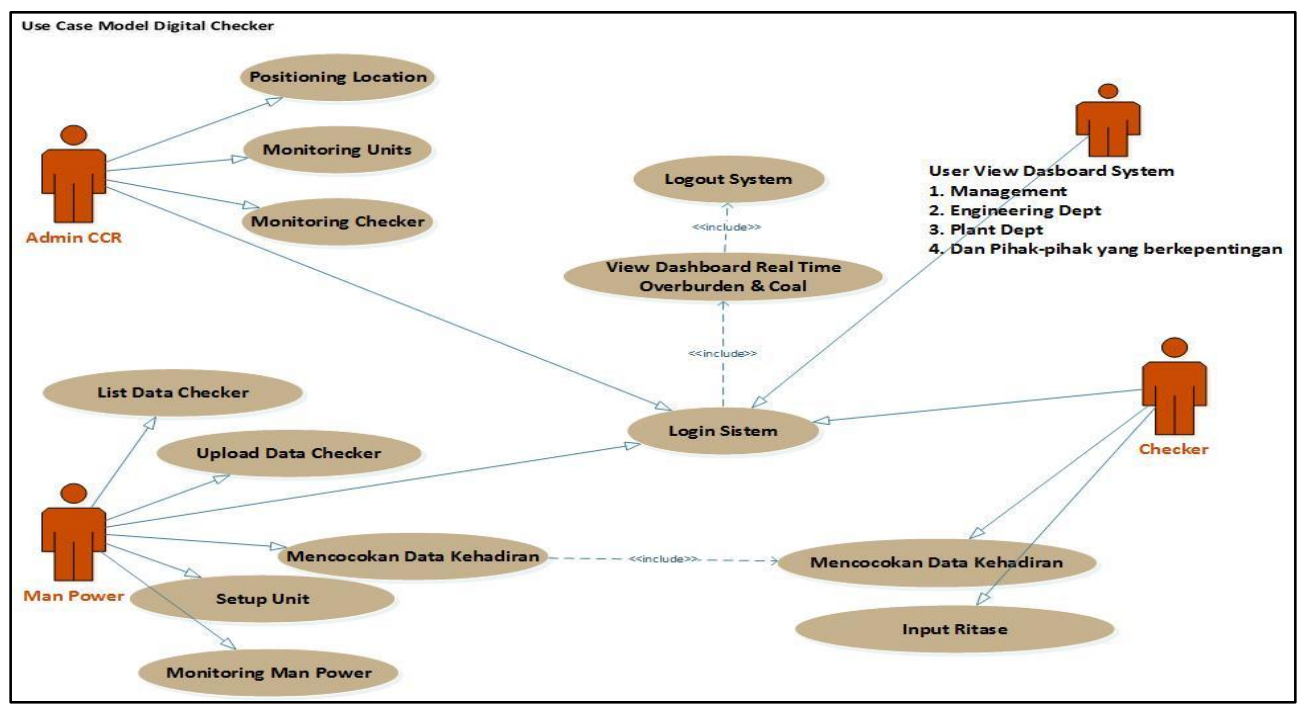

Gambar 3. Use Case Alur proses checker digital

Selanjutnya hasil dari penelitian pengembangan sistem aplikasi digital checker berbasis android sudah siap untuk digunakan. Pengembangan aplikasi digital checker di implementasikan menjadi dua aplikasi yang saling memiliki hubungan satu sama lain, yaitu berbasis web dan android. Aplikasi yang berbasis web digunakan oleh administrator sistem, dan real time data akan di tampilkan dalam bentuk web. Sedangkan aplikasi android akan digunakan oleh checker untuk input data ritase. Berikut ini uraianya.

\section{C.1. Aplikasi berbasis web}

Implementasi user interface dari aplikasi digital checker berbasis web adalah sebagai berikut:

a. Halaman user equipmet ; Halaman ini merupakan sistem interface yang digunakan oleh manpower untuk melakukan setup units, nama operator sesuai dengan kehadiran dan lain sebagainya. Gambar adalah real time data yang diambil pada tanggal 14 September 2019, shift malam.

b. Menu shift display

Menu shift display digunakan untuk melihat hasil setup units, nama operator dan lokasi tambang. Lebih lanjut dapat dilihat pada gambar 5 menu shift display di PIT1UB-PIT 1 Utara. Kemudian checker akan mencocokan data yang diberikan oleh manpower sesuai dengan spesifikasi sebelum melakukan input ritase. 


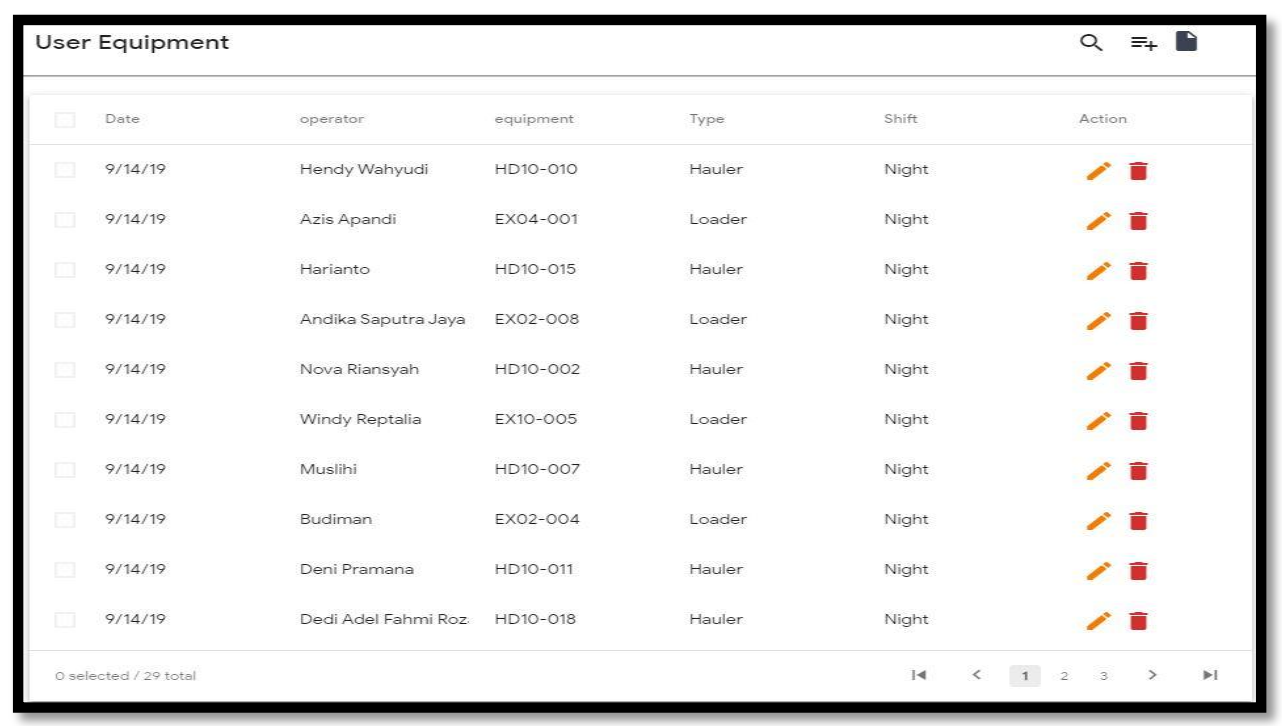

Gambar 4. Menu actual setup units, kehadiran operator dan lain-lain.

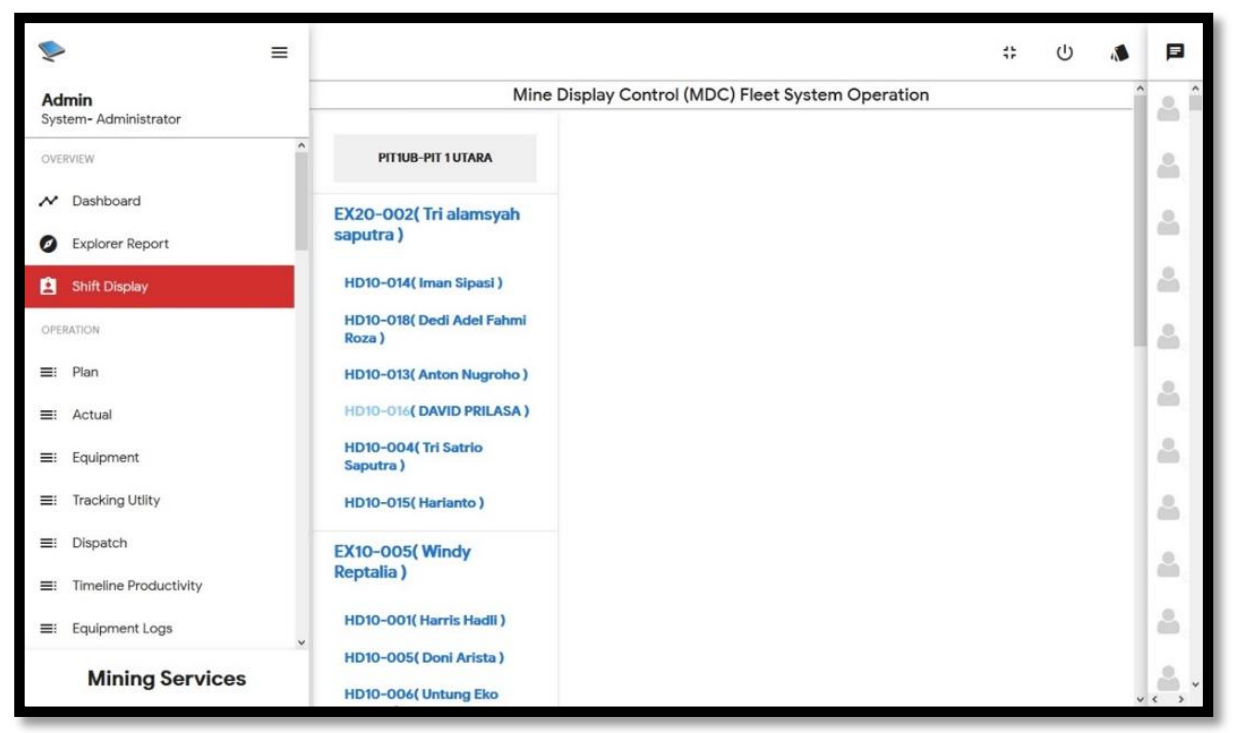

Gambar 5. Menu shift display

\section{c. Menu dashboard}

Menu dashboard merupakan output tampilan yang dapat melihat data secara real time. Data real time di dapatkan dari aktifitas setup yang sudah di buat oleh manpower dan checker secara konsisten melakukan input data ritase, baik overburden maupun coal maka mendapatkan hasil yang real time sesuai dengan gambar 6 menu dashboard dibawah ini.

Dari gambar 6 menu dashboard terlihat real time data yang dapat di analisa dari model grafik menunjukan aktifitas input ritase overburden di mulai dari pukul 08.00 WIB. Informasi input ritase overburden setiap satu jam sekali dapat diketahui dengan cepat. Nilai rata-rata tertinggi produksi dari hasil ritase mulai dari pukul 09.00 WIB sampai dengan pukul 23.00 WIB yang terbagi dalam dua shift di pit1 utara pada tanggal 14 September 2019 adalah berkisar antara 1000 Bank Cubic Metre (BCM) sampai dengan 1200 BCM. Ada terjadi lonjakan grafik tertinggi pada pukul 20.00 WIB mencapai 1981 BCM. Untuk mempermudah pemahaman informasi terkait yang sudah penulis jelaskan sebelumnya maka penulis melakukan pemetaan grafik setiap satu jam sekali (Gambar 7). 


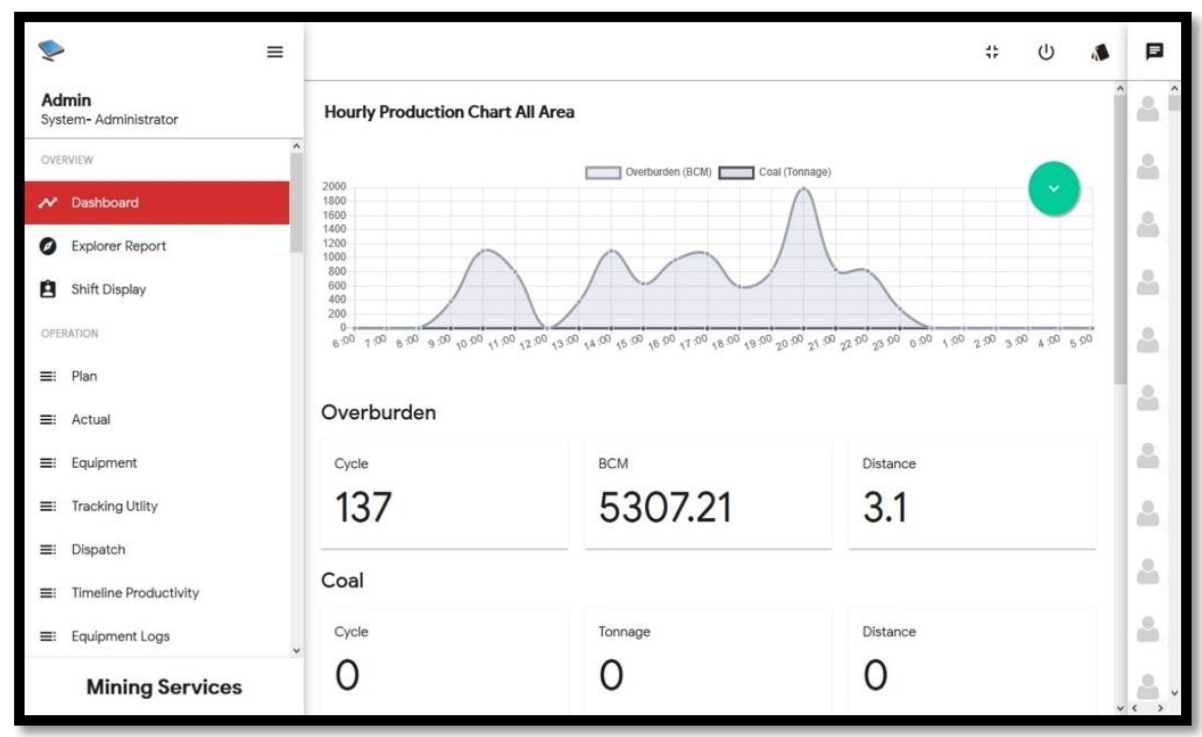

Gambar 6. Dashboard data real time overburden dan coal

\section{C.2. Aplikasi berbasis Android}

Implementasi user interface checker menggunakan smartphone berbasis aplikasi android terdiri dari menu login dan input ritase checker. Pada menu login di isi dengan Nomor Registrasi Pegawai (NRP), dalam hal ini NRP khusus dapat digunakan adalah NRP checker yang sedang bertugas sesuai dengan shift pagi atau malam. Ketika sudah login, checker tinggal menekan tombol tambah $(+)$ atau kurang (-) melalui aplikasi android untuk setiap ritasenya.

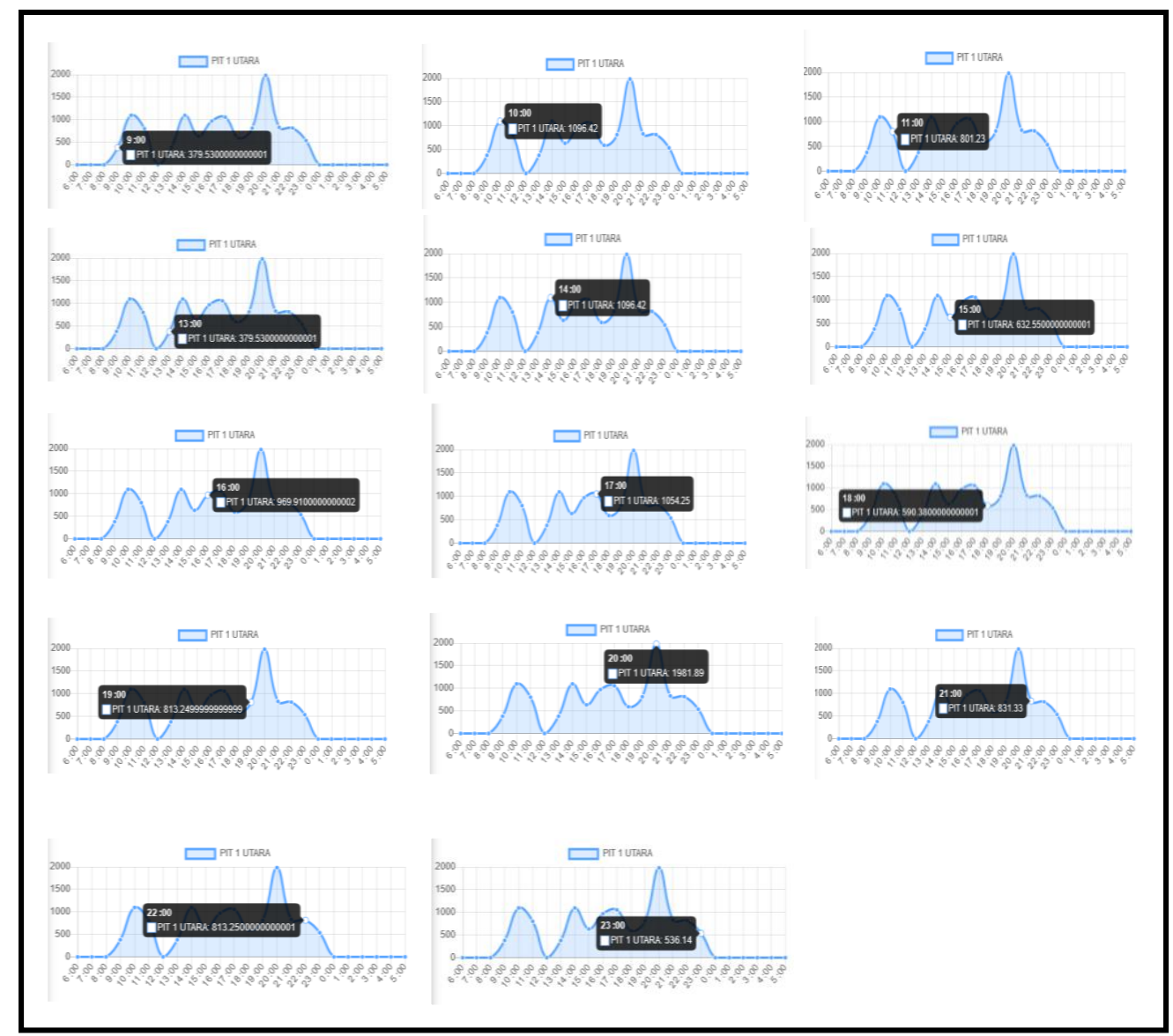

Gambar 7. Pemetaan grafik overburden setiap satu jam sekali 


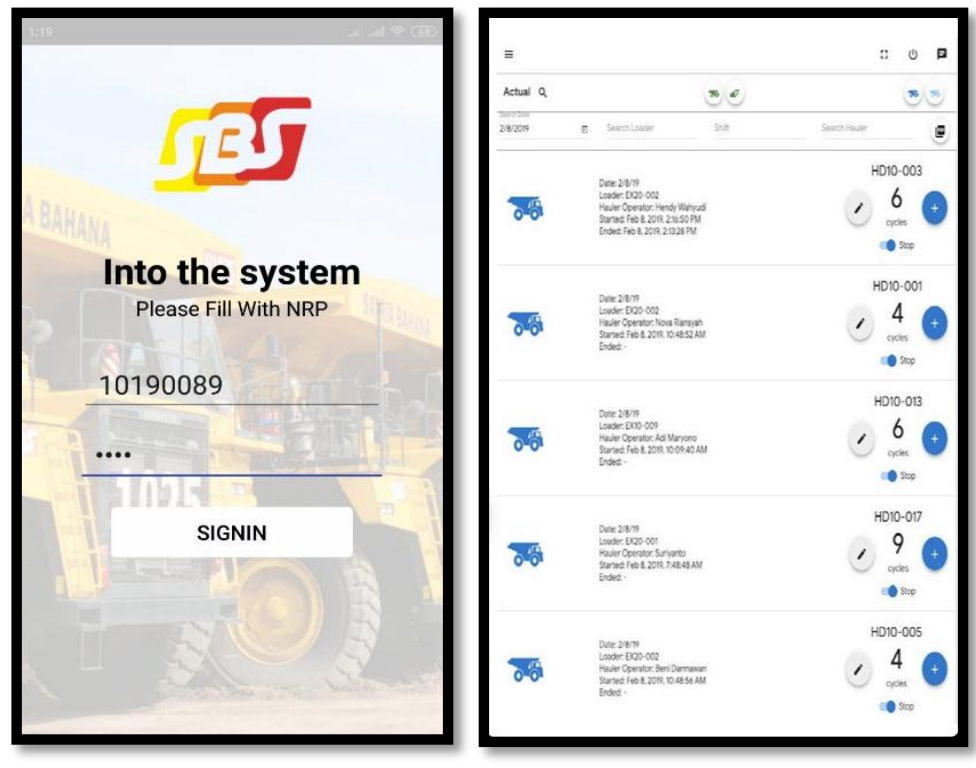

Gambar 8. Menu login dan input ritase

\section{KESIMPULAN}

Setelah melakukan penelitian dan menghasilkan aplikasi digital checker berbasis android serta uji coba penggunaan aplikasi secara langsung di lapangan (site Banko PIT1-Utara dan site Mahayung) maka sampailah penulis pada kesimpulan. Adapun kesimpulan dalam penelitian antara lain adalah sebagai berikut :

1. Pengembangan aplikasi digital checker berbasis android sebagai pencatatan ritase secara real time dapat di eksekusi dengan menggunakan metode 4D.

2. Berdasarkan hasil uji coba di lapangan pada lokasi site Banko pit 1 utara dan site Mahayung maka hasilnya adalah dapat mempercepat efesiensi waktu untuk mengetahui pencapaian produksi, baik itu overburden maupun batubara. Management dapat mengambil keputusan dengan cepat terkait informasi produksi yang di dapatkan secara real time dan melakukan perencanaan lainnya. Dan juga aplikasi digital checker ini dapat mengurangi penumpukan dan pemakaian kertas untuk pencatatan ritase oleh checker.

\section{UCAPAN TERIMA KASIH}

Dalam penyusunan makalah ini tidak terlepas dari dukungan dan bantuan berbagai pihak. Penulis mengucapkan terima kasih kepada semua pihak yang telah membantu hingga makalah ini dapat terselesaikan. Penulis banyak mendapatkan bimbingan, petunjuk, dan bantuan serta dorongan dari berbagai pihak baik yang bersifat moril mapun materil. Pada kesempatan ini penulis menyampaikan terima kasih kepada :

1. Allah SWT dengan segala rahmat dan karunia-Nya memberikan kekuatan bagi penulis dalam menyelesaikan makalah ini.

2. Kepada Bpk. FX Sigit Hery Basuki (Presiden Director), Agus Sunaryadi (Finance \& HCGS Director), Vicky Agustian (Production Director), Irwan Daulima (Plant Director) dan Andrie Mustika Rainy (Vice President Finace \& Accounting). Terima kasih atas dukungan dan arahannya.

3. Kepada semua kepala department (HC, OCC, Engineering, Plant, FA, Legal, HSE, Learning Center dan lain-lain), Tim Konsultan Pertambangan Tura Technology. Terima kasih atas kerja samanya. 
4. Kepada teman-teman Management Information System (Karmono, Ahmad Isnaini Sugiarta, Harmoko, Thahir Kurniawan, Loka Prayoga dan Vita Apriani). Terima kasih, karena kerja sama tim yang hebat dan solidlah kita bisa, "Continuous Improvement".

5. Serta masih banyak lagi pihak-pihak yang sangat menginspirasi dalam penyelesaian makalah ini, mohon maaf tidak dapat penulis sebutkan satu persatu.

Semoga Allah SWT senantiasa memberikan balasan atas kebaikan yang sudah diberikan. Semoga makalah ini bermanfaat bagi peneliti pada umumnya dan kepada para pembaca.

\section{DAFTAR PUSTAKA}

Anhar. (2010) : Panduan Menguasai PHP \& MySQL secara otodidak, Jakarta, Mediakita.

https://www.nesabamedia.com/pengertian-php-dan-fungsinya/. Diunduh pada tanggal 9 September 2019 Pukul 21.30 WIB.

https://medium.com/@arifwicaksanaa/pengertian-use-case-a7e576e1b6bf. Diunduh pada tanggal 12 September 2019 Pukul 11.14 WIB.

Juhara Z.P. (2016) : Panduan Lengkap Pemrograman Android, Yogyakarta, Andi.

Meta, Monanda Rio, (2017) : Pengembangan Perangkat Pembelajaran Berbasis Web Pada Mata Pelajaran Kkpi Smkn 3 Padang, Jurnal Sains dan Informatika, Research of Science and Informatic, 3, 17-21.

Ningsih, M. (2019) : Pengaruh Perkembangan Revolusi Industri 4.0 dalam Dunia Teknologi di Indonesia, Fakultas Komputer, Universitas Mitra Indonesia Lampung, 12,2.

Prodjosumarto, P. (1993) : Pemindahan Tanah Mekanis, Departemen Pertambangan Insitut Teknologi Bandung.

Turatech, (2018) : Pengembangan Aplikasi Checker Digital PT. Satria Bahana Sarana, Pendampingan IT Tahap I, Turatech, PT. SBS, Tanjung Enim. Kab. Muara Enim.

Zuriah. (2003) : Penelitian Tindakan dalam Bidang Pendidikan dan Sosial, Malang, Banyu Publishing. 
PROSIDING TPT XXVIII PERHAPI 2019 